\title{
Antiallergic and Anti-inflammatory Properties of the Ethanolic Extract from Gleditsia sinensis
}

\author{
Yue DAI, ${ }^{a, b}$ Yiu-Pong Chan, ${ }^{a}$ Lee-Man ChU, ${ }^{a}$ and Paul Pui-Hay BUT*, \\ ${ }^{a}$ Department of Biology and Institute of Chinese Medicine, The Chinese University of Hong Kong; Shatin, Hong Kong, \\ China: and ${ }^{b}$ Department of Pharmacology of Chinese Materia Medica, China Pharmaceutical University; 1 Shennong \\ Road, Nanjing 210038, China. Received February 25, 2002; accepted May 23, 2002
}

\begin{abstract}
This study was carried out to determine the effects of the $70 \%$ ethanolic extract from the anomalous fruits of Gleditsia sinensis LAM. (AFGS) on experimental allergic reactions and inflammation. AFGS (200, 500, 1000 $\mathrm{mg} / \mathrm{kg}$, p.o.) dose-dependently inhibited the systemic anaphylactic shock induced by compound 48/80 in mice and cutaneous reactions induced by histamine or serotonin in rats. At doses of 500 and $1000 \mathrm{mg} / \mathrm{kg}$, AFGS showed a clear inhibition on homologous passive cutaneous anaphylaxis in rats. In vitro, AFGS significantly reduced histamine release from rat peritoneal mast cells triggered by compound $48 / 80$ at concentrations of 20 and $50 \mu \mathrm{g} / \mathrm{ml}$. Moreover, AFGS $(500,1000 \mathrm{mg} / \mathrm{kg}$, p.o. $)$ showed a significant inhibition on the hind paw edema in rats and ear swelling in mice caused by carrageenin and croton oil, respectively. It also clearly inhibited the vascular permeability induced by acetic acid in mice at a dose of $1000 \mathrm{mg} / \mathrm{kg}$. These findings demonstrate that the ethanolic extract from the anomalous fruits of Gleditsia sinensis possesses antiallergic and anti-inflammatory activities, which may be mediated by reducing the release of mediators such as histamine from mast cells and weakening the inflammatory action of these mediators.
\end{abstract}

Key words Gleditsia sinensis; passive cutaneous anaphylaxis; mast cell; inflammation; vascular permeability

In traditional Chinese medicine, various parts of Gleditsia sinensis Lam. (Leguminosae) are used for different remedies and express specific therapeutic values. The thorns of $G$. sinensis are used for the treatment of carbuncle, scabies and suppurative skin diseases, while the mature pods and anomalous fruits (fruits without seeds) are mainly used for treating apoplexy, headache, productive cough, asthma and scabies. ${ }^{1)}$ The thorns of G. sinensis have been reported to show inhibitory effects on mast cell-dependent anaphylaxis and on the growth of nasopharyngeal carcinoma cells. ${ }^{2,3)}$ However, little research has been done to identify the pharmacological properties of the pods and the anomalous fruits of $G$. sinensis.

Phytochemical investigations have shown that the anomalous fruits of $G$. sinensis contain over ten kinds of oleananetype triterpenoidal saponins. ${ }^{4-6)}$ Research has demonstrated that oleanolic acid, oleanane-type triterpenoidal saponins and herb medicines rich in this kind of saponin possess antiallergic and anti-inflammatory activities. ${ }^{7-12)}$ Thus, the present study was undertaken to evaluate the effects of the $70 \%$ ethanolic extract from the anomalous fruits of $G$. sinensis on immediate allergic reactions and acute inflammation.

\section{MATERIALS AND METHODS}

Preparation of Extract The anomalous fruits of Gleditsia sinensis were purchased from an herbal market in Nanjing, China in October 2001. A voucher specimen (Dai 0103) is deposited in the Department of Pharmacology of Chinese Materia Medica, China Pharmaceutical University. Two hundreds grams of Gleditsia sinensis fruits were ground and refluxed with $70 \%$ ethanol $(1.5 \mathrm{l})$ three times for $1 \mathrm{~h}$. After filtration through filter paper, the clear supernatant was concentrated under reduced pressure at $45^{\circ} \mathrm{C}$ with a vacuum rotary evaporator, and lyophilized to give a dry extract $(74.1 \mathrm{~g})$. The extract (AFGS) was freshly prepared in distilled water or physiological buffer saline (PBS) just before use.
Chemicals and Reagents Compound 48/80, ovalbumin (chicken egg, Grade V), croton oil, carrageenin, 5-hydroxytryptamine hydrochloride (serotonin) and indomethacin were purchased from Sigma (St. Louis, MO, U.S.A.). Inactive bacterial suspension of Bordetella pertussis, o-phthalaldehyde (OPT), prednisolone and histamine dihydrochloride were from Wako (Osaka, Japan), and disodium cromoglycate (DSCG) was from Biomol (PA, U.S.A.). Other reagents used were of analytical grade. All reagents were dissolved in distilled water for oral administration or in physiological saline for subcutaneous and intraperitoneal administration.

Animals Male SD rats (weighing 180-220 g) and male ICR mice (weighing 18-20 g, 24-26g) from the animal center of The Chinese University of Hong Kong were used. They were maintained on a standard pellet diet with free access to water, and housed in an air-contained room at $24 \pm$ $2{ }^{\circ} \mathrm{C}$ with lighting from 8:00 to 20:00.

Systemic Anaphylactic Shock Induced by Compound 48/80 in Mice The experiment was carried out according to the method of Shin et al. ${ }^{13)}$ Mice were given an intraperitoneal injection of $10 \mathrm{mg} / \mathrm{kg}$ of compound $48 / 80$. Mortality during the $\mathrm{h}$ after induction of the systemic anaphylactic reaction was monitored. AFGS was orally administered $1 \mathrm{~h}$ before the injection of compound 48/80.

Passive Cutaneous Anaphylaxis (PCA) in Rats Rat anti-ovalbumin serum containing IgE was prepared as earlier described. ${ }^{11)}$ In brief, rats were immunized with $0.5 \mathrm{ml}$ of suspension containing $1 \mathrm{mg}$ of ovalbumin and $10 \mathrm{mg}$ of aluminum hydroxide gel (s.c.) and $1 \mathrm{ml}$ of inactive bacterial suspension of Bordetella pertussis $\left(2 \times 10^{10}\right.$ cells $/ \mathrm{ml}$, i.p. $)$, simultaneously. Seven days later, they were immunized again following the same procedure. Fourteen days later, rats were anesthetized with ketamine and xylazine, and blood was withdrawn from the carotid artery; then rat anti-ovalbumin serum was separated. The anti-OVA IgE antibody was determined by PCA in rats, and the titer $(1: 32)$ was expressed as 
the highest dilution causing a lesion more than $5 \mathrm{~mm}$ in diameter.

The antiserum diluted 4-fold with saline $(50 \mu \mathrm{l})$ was intradermally injected into 2 sites on the shaved dorsal skin of rats. After $48 \mathrm{~h}$, rats were challenged with $0.5 \mathrm{ml}$ of saline containing $2 \mathrm{mg}$ of ovalbumin and $5 \mathrm{mg}$ of Evans blue via the tail vein. After $30 \mathrm{~min}$, the animals were sacrificed, and the skin surrounding spots were removed. After incubation with $1 \mathrm{~N} \mathrm{KOH}$, the dye that had leaked into the spots was extracted with a mixture of acetone and phosphoric acid, and was determined colorimetrically. AFGS was orally administered $1 \mathrm{~h}$ before the challenge of ovalbumin. DSCG was intravenously injected just before the challenge.

Histamine Release from Rat Peritoneal Mast Cells As previously described, ${ }^{14)}$ mixed rat peritoneal cells were collected by peritoneal lavage and were purified by centrifugation through Ficoll density gradient. Purified mast cells were washed and resuspended in PBS $(\mathrm{NaCl} 154 \mathrm{~mm}, \mathrm{KCl} 2.7 \mathrm{~mm}$, $\mathrm{CaCl}_{2} 0.9 \mathrm{~mm}, \mathrm{Na}_{2} \mathrm{HPO}_{4} 4 \mathrm{~mm}, \mathrm{KH}_{2} \mathrm{PO}_{4} 2.7 \mathrm{~mm}$, glucose 5.6 $\mathrm{mm}$ and $0.1 \%$ bovine serum albumin). Mast cell preparations were about $92 \%$ pure as assessed by toluidine blue staining. Cell viability was confirmed to be around $90 \%$ before and after experiments by the trypan blue exclusion test.

Purified mast cells $\left(2 \times 10^{6}\right.$ cells $\left./ \mathrm{ml}\right)$ were preincubated at $37^{\circ} \mathrm{C}$ for $10 \mathrm{~min}$. Then, AFGS and DSCG dissolved in PBS were added $5 \mathrm{~min}$ before activation by compound $48 / 80$ $(0.5 \mu \mathrm{g} / \mathrm{ml})$. The reaction was stopped $10 \mathrm{~min}$ later by chilling the test tubes in ice water. The supernatant and cell pellets were then separated by centrifugation, and $0.05 \%$ Triton100 was added to the cell pellets to liberate the residual histamine. After addition of $0.036 \%$ OPT methanol solution, histamine content in supernatant (Supernatant) and cell pellets (Cell pellet) was determined spectrofluorometrically (Em $360 \mathrm{~nm}$, Ex $450 \mathrm{~nm}$ ). To estimate the spontaneous release of histamine (Spontaneous), exactly the same procedure was followed but without adding samples or compound 48/80. The release percentage of histamine was calculated by the following equation.

histamine release $(\%)=[($ supernatant - spontaneous $) /$ (supernatant + cell pellet) $] \times 100 \%$

Skin Reactions Induced by Histamine and Serotonin in Rats Histamine- and serotonin-induced cutaneous reactions were carried out as previously described. ${ }^{15)}$ Briefly, 50 $\mu \mathrm{l}$ of histamine $(2 \mu \mathrm{g})$ and serotonin $(0.02 \mu \mathrm{g})$ were intradermally injected into the spots on the shaved dorsal skin of rats, respectively. Thereafter, $1 \mathrm{ml}$ of physiological saline containing $5 \mathrm{mg}$ of Evans blue was immediately injected into the tail vein. AFGS and prednisolone were orally administered $1 \mathrm{~h}$ before challenge. Animals were sacrificed by bleeding 30 min after the induction of reactions, and the skin surrounding each reaction spot was cut off, from which the extravasated dye was extracted and assayed using the method described in rat PCA.

Hind Paw Edema Induced by Carrageenin in Rats The acute hind paw edema was produced by subcutaneously injecting $0.1 \mathrm{ml}$ of $1 \%$ carrageenin, suspended in sterile physiological saline, into the right hind paw of the rats. AFGS and indomethacin were orally administered $1 \mathrm{~h}$ prior to the injection of carrageenin. The rat pedal volume up to the ankle joint was measured just before and 1 or $3 \mathrm{~h}$ after the
Table 1. Effect of AFGS on Compound 48/80-Induced Anaphylactic Shock in Mice

\begin{tabular}{lccc}
\hline \hline Treatment & $\begin{array}{c}\text { Dose } \\
(\mathrm{mg} / \mathrm{kg})\end{array}$ & $n$ & $\begin{array}{c}\text { Mortality } \\
(\%)\end{array}$ \\
\hline Control & - & 10 & 90 \\
AFGS & 200 & 10 & 60 \\
& 500 & 10 & 50 \\
& 1000 & 10 & 30
\end{tabular}

Mice were orally given AFGS $1 \mathrm{~h}$ prior to intraperitoneal injection of compound $48 / 80(10 \mathrm{mg} / \mathrm{kg})$. Mortality rate (\%) within $1 \mathrm{~h}$ after the injection of this compound was represented as number of dead mice $\times 100 /$ total number of experimental mice.

injection of carrageenin. Data were expressed as a percentage increase of paw volume in relation to the initial values.

Vascular Permeability Induced by Acetic Acid in Mice Mice received an intravenous injection of $0.5 \%$ Evans blue saline solution and an intraperitoneal injection of $0.6 \%$ acetic acid $(10 \mathrm{ml} / \mathrm{kg})$. After $20 \mathrm{~min}$, the dye that leaked into the peritoneal cavity was collected by lavaging with $10 \mathrm{ml}$ of distilled water. After centrifugation, the amount of dye was measured colorimetrically. AFGS and indomethacin were orally administered $1 \mathrm{~h}$ prior to the injection of acetic acid.

Ear Swelling Induced by Croton Oil in Mice The croton oil ear test was performed as described. ${ }^{16)}$ Each mouse received $15 \mu \mathrm{l}$ of an acetone solution of croton oil on the inner surface of the right ear ( $75 \mu \mathrm{g}$ croton oil/ear). After $6 \mathrm{~h}$, the animals were sacrificed by cervical dislocation, and thickness of the ears was measured by a dial thickness gauge. The swelling percentage was determined in relation to the thickness of untreated left ears. AFGS and indomethacin were orally administered $1 \mathrm{~h}$ prior to the application of croton oil.

Statistics All values were presented as mean values \pm S.D. The statistical significance between groups was calculated by analysis of variance of the Student's $t$-test. All $p$ values less than $0.05(p<0.05)$ were considered significant.

\section{RESULTS}

Effect on Systemic Anaphylactic Shock Induced by Compound 48/80 in Mice As shown in Table 1, an intraperitoneal injection of compound $48 / 80(10 \mathrm{mg} / \mathrm{kg})$ resulted in a fatal shock in $90 \%$ of mice, and AFGS pretreatment $(200,500,1000 \mathrm{mg} / \mathrm{kg}$, p.o. $)$ dose-dependently reduced the mortality rate.

Effect on Passive Cutaneous Anaphylaxis (PCA) in Rats AFGS (500, $1000 \mathrm{mg} / \mathrm{kg}$, p.o. $)$ and DSCG $(2 \mathrm{mg} / \mathrm{kg}$, i.v.) clearly inhibited PCA in rats by $50 \%, 56.8 \%$ and $62.5 \%$, respectively. However, AFGS $(200 \mathrm{mg} / \mathrm{kg})$ did not affect PCA (Fig. 1).

Effect on Histamine Release from Rat Peritoneal Mast Cells Induced by Compound 48/80 The spontaneous release of histamine from rat peritoneal mast cells was $9.4 \%$. Compound $48 / 80(0.5 \mu \mathrm{g} / \mathrm{ml})$ elicited about $80 \%$ histamine release from mast cells. AFGS $(20,50 \mu \mathrm{g} / \mathrm{ml})$ pretreatment significantly reduced the release by $35.7 \%$ and $53.5 \%$, respectively. DSCG, a stabilizer of mast cell membrane, also clearly reduced the histamine release at a concentration of $500 \mu \mathrm{g} / \mathrm{ml}$. However, AFGS $(5 \mu \mathrm{g} / \mathrm{ml})$ did not affect the release (Fig. 2). 


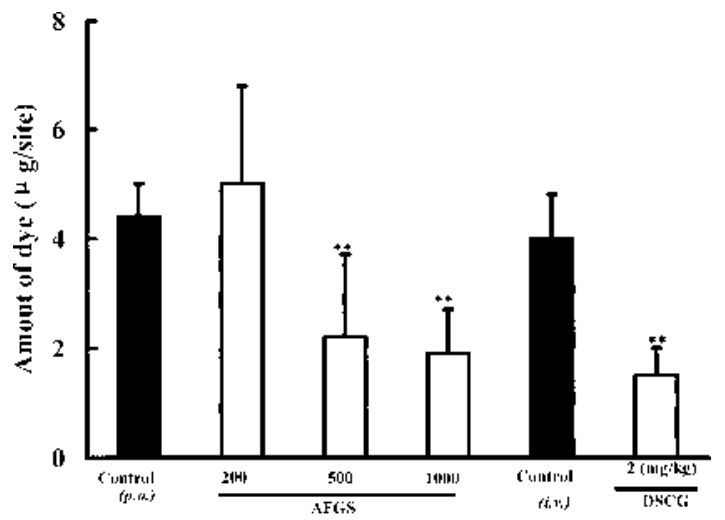

Fig. 1. Effects of AFGS and DSCG on Passive Cutaneous Anaphylaxis (PCA) in Rats

Diluted rat anti-ovalbumin serum $(50 \mu \mathrm{l})$ was intradermally injected into spots on the dorsal skin of rats. After $48 \mathrm{~h}$, rats were challenged with $2 \mathrm{mg}$ of ovalbumin and $5 \mathrm{mg}$ of Evans blue via tail vein. After $30 \mathrm{~min}$, animals were sacrificed, and the amount of dye that leaked into the spots was determined. The amount of dye in the skin without reaction was $0.4 \pm 0.2 \mu \mathrm{g} / \mathrm{site}$. AFGS was orally administered $1 \mathrm{~h}$ before the challenge of antigen, and DSCG was intravenously injected just before the challenge. Data are means \pm S.D. of 5 rats. $* * p<0.01$.

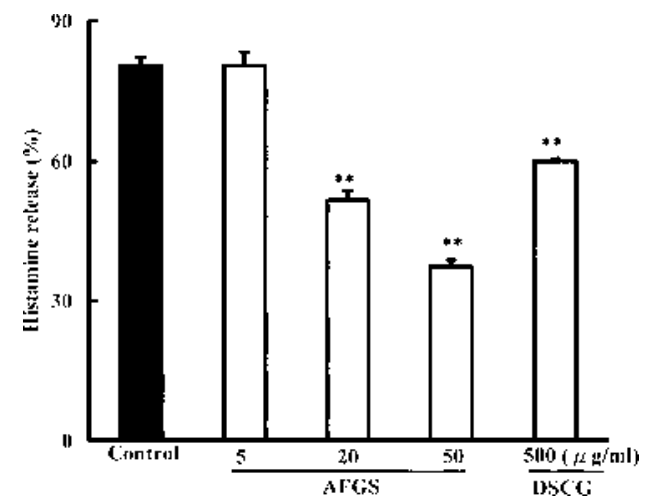

Fig. 2. Effects of AFGS and DSCG on Compound 48/80-Induced Histamine Release from Rat Peritoneal Mast Cells

Purified mast cells $\left(2 \times 10^{6} \mathrm{cells} / \mathrm{ml}\right)$ were preincubated at $37^{\circ} \mathrm{C}$ for $10 \mathrm{~min}$. Then, test samples dissolved in PBS were added 5 min before activation by compound $48 / 80$ $(0.5 \mu \mathrm{g} / \mathrm{ml})$. The reaction was stopped $10 \mathrm{~min}$ later. After centrifugation, histamine contents in supernatant and cell pellets were determined. Data are means \pm S.D. of 3 experiments. $* * p<0.01$.

Effect on Cutaneous Reactions Induced by Histamine and Serotonin in Rats Cutaneous reactions were elicited by an intradermal injection of histamine $(2 \mu \mathrm{g})$ and serotonin $(0.02 \mu \mathrm{g})$, respectively. AFGS $(200,500,1000 \mathrm{mg} / \mathrm{kg}$, p.o. $)$ dose-dependently reduced the skin reaction induced by histamine, and it also showed a clear inhibition on the skin reaction induced by serotonin at doses of 500 and $1000 \mathrm{mg} / \mathrm{kg}$. Prednisolone, a steroidal anti-inflammatory agent, significantly inhibited the reactions at a dose of $20 \mathrm{mg} / \mathrm{kg}$ (Fig. 3).

Effect on Hind Paw Swelling Induced by Carrageenin in Rats As shown in Fig. 4, a subcutaneous injection of carrageenin $(1 \%, 0.1 \mathrm{ml})$ into the hind paw of rats produced $21.3 \%$ and $50.8 \%$ of swelling at 1 and $3 \mathrm{~h}$ after the injection, respectively. AFGS $(200,500,1000 \mathrm{mg} / \mathrm{kg}$, p.o. $)$ reduced the hind paw swelling at 1 and $3 \mathrm{~h}$ in a dose-dependent manner. Indomethacin, a nonsteroidal anti-inflammatory agent, also significantly inhibited the hind paw swelling at a dose of $10 \mathrm{mg} / \mathrm{kg}$.

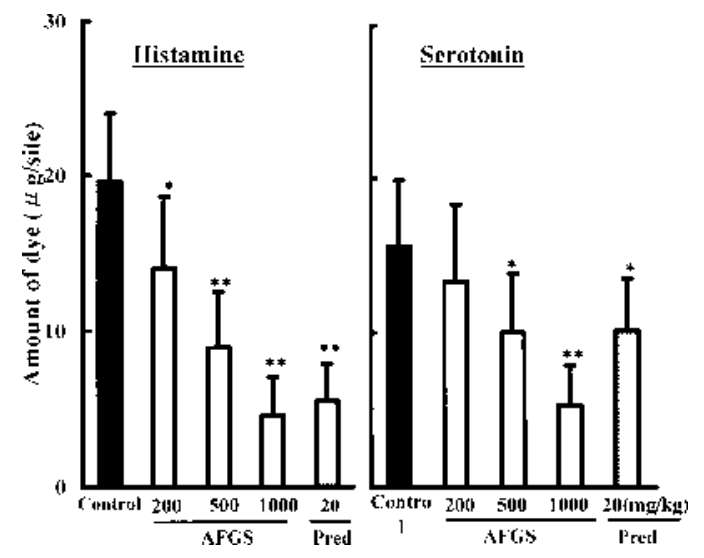

Fig. 3. Effects of AFGS and Prednisolone (Pred) on Histamine- or Serotonin-Induced Permeability in Rats

Histamine $(2 \mu \mathrm{g})$ and serotonin $(0.02 \mu \mathrm{g})$ were intradermally injected into the spots on the dorsal skin of rats, respectively. Thereafter, $1 \mathrm{ml}$ of saline solution containing 5 $\mathrm{mg}$ of Evans blue was immediately injected into the tail vein. AFGS and prednisolone were orally administered $1 \mathrm{~h}$ before challenge. Rats were sacrificed $30 \mathrm{~min}$ after the induction of reactions, and the amount of dye that leaked into the spots was determined. Data are means \pm S.D. of 7 rats. $* p<0.05, * * p<0.01$.

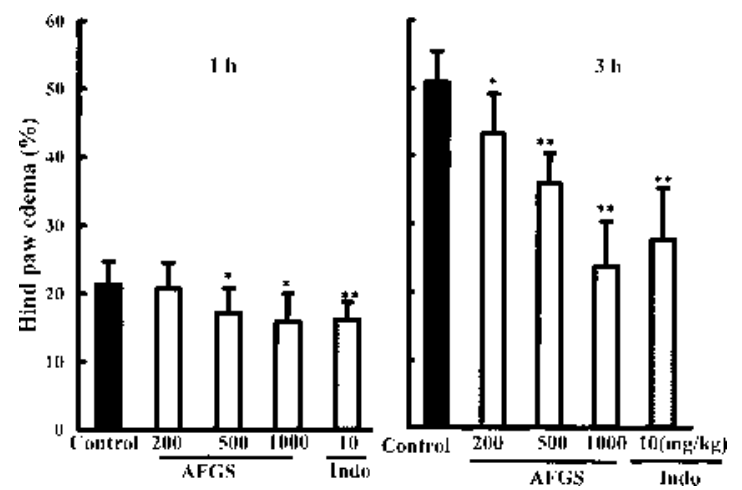

Fig. 4. Effects of AFGS and Indomethacin (Indo) on Hind Paw Swelling Induced by Carrageenin in Rats

Carrageenin $(1 \%, 0.1 \mathrm{ml})$ was subcutaneously injected into the right hind paw of rats. The volume of that paw was measured just before and $1,3 \mathrm{~h}$ after the injection, and swelling of the paw was expressed as a percentage increase in paw volume in relation to the initial values. AFGS and indomethacin were orally administered $1 \mathrm{~h}$ prior to the injection of carrageenin. Data are means \pm S.D. of 8 rats. $* p<0.05, * * p<0.01$.

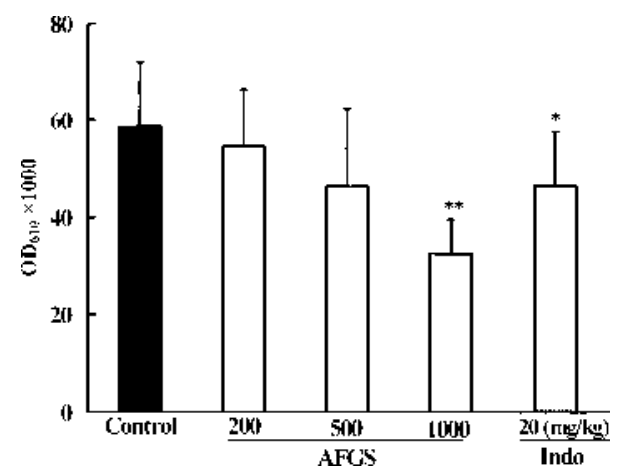

Fig. 5. Effects of AFGS and Indomethacin (Indo) on Vascular Permeability Induced by Acetic Acid in Mice

Mice received an intravenous injection of $0.5 \%$ Evans blue and an intraperitoneal injection of $0.6 \%$ acetic acid $(10 \mathrm{ml} / \mathrm{kg})$. After $20 \mathrm{~min}$, the animals were sacrificed, and the dye that leaked into the peritoneal cavity was measured. AFGS and indomethacin were orally administered $1 \mathrm{~h}$ prior to the injection of acetic acid. Data are means \pm S.D. of 10 mice. $* p<0.05, * * p<0.01$. 


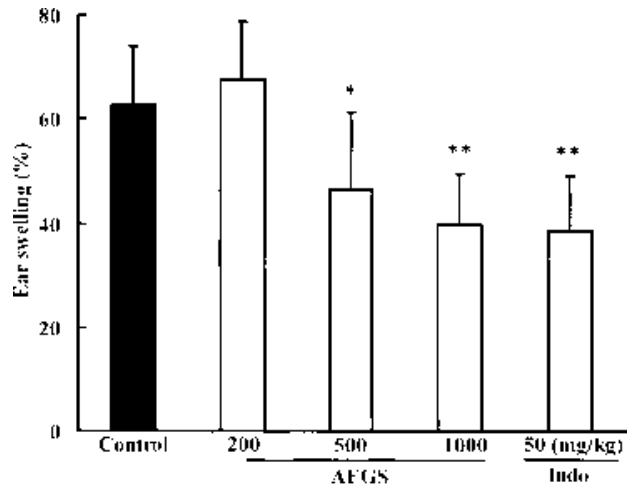

Fig. 6. Effects of AFGS and Indomethacin (Indo) on Ear Swelling Induced by Croton Oil in Mice

Croton oil ( $75 \mu \mathrm{g} /$ mouse) was applied to the right ears of mice. After $6 \mathrm{~h}$, the animals were sacrificed, and the thickness of ears was measured. The swelling percentage was determined in relation to the thickness of untreated left ears. AFGS and indomethacin were orally administered $1 \mathrm{~h}$ prior to the application of croton oil. Data are means \pm S.D. of 8 mice. $* p<0.05, * * p<0.01$

Effect on Vascular Permeability Induced by Acetic Acid in Mice AFGS $(200,500,1000 \mathrm{mg} / \mathrm{kg}$, p.o.) dose-dependently reduced the plasma exudation induced by acetic acid in mice. Significant difference was observed at a dose of $1000 \mathrm{mg} / \mathrm{kg}$. Indomethacin $(20 \mathrm{mg} / \mathrm{kg}$, p.o. $)$ also clearly inhibited the exudation (Fig. 5).

Effect on Ear Swelling Induced by Croton Oil in Mice As shown in Fig. 6, the average swelling of mouse ears reached $62.6 \%$ at $6 \mathrm{~h}$ after the application of croton oil. AFGS $(500,1000 \mathrm{mg} / \mathrm{kg}$, p.o. $)$ and indomethacin $(50 \mathrm{mg} / \mathrm{kg}$, p.o.) significantly inhibited the ear swelling by $25.9 \%, 36.6 \%$ and $38.5 \%$, respectively. AFGS $(200 \mathrm{mg} / \mathrm{kg})$ did not affect the swelling.

\section{DISCUSSION}

In the present study, the antiallergic and anti-inflammatory properties of the $70 \%$ ethanolic extract from the anomalous fruits of Gleditsia sinensis (AFGS) were evaluated by different experimental models. AFGS dose-dependently inhibited homologous passive cutaneous anaphylaxis in rats and systemic anaphylactic shock in mice mediated by the vasoactive substances histamine and serotonin secreted from mast cells and basophils due to compound 48/80. ${ }^{13}$ In order to explore the mechanisms by which AFGS reduced immediate allergic reactions, we observed the effects on histamine release from mast cells and the inflammatory action of mediators. Results showed that in vitro AFGS $(20,50 \mu \mathrm{g} / \mathrm{ml})$ exhibited a significant and more potent inhibition on histamine release from rat peritoneal mast cells triggered by compound $48 / 80$ than DSCG $(500 \mu \mathrm{g} / \mathrm{ml})$, and in vivo AFGS clearly reduced the skin reactions induced by histamine and serotonin in rats at doses of 500 and $1000 \mathrm{mg} / \mathrm{kg}$. These findings suggest that the antiallergic activities of AFGS are probably mediated by reducing the release of mediators such as histamine from mast cells and weakening the inflammatory action of these mediators.

Shin and $\mathrm{Kim}^{2)}$ reported that the aqueous extract from thorns of $G$. sinensis inhibited systemic and local anaphy- laxis induced by compound 48/80 and anti-DNP IgE, respectively, and reduced the histamine level in plasma and in vitro histamine release from rat peritoneal mast cells. Taken together with our findings, it can be suggested that the anomalous fruits of $G$. sinensis share a common mode of action on immediate allergic reactions with the thorns of $G$. sinensis.

Furthermore, the effect of AFGS on acute inflammation was observed. AFGS $(500,1000 \mathrm{mg} / \mathrm{kg}$, p.o.) showed a significant inhibition on the hind paw edema in rats and ear swelling in mice caused by carrageenin and croton oil, respectively. It also showed a clear inhibition on the vascular permeability induced by acetic acid in mice at a dose of $1000 \mathrm{mg} / \mathrm{kg}$. As mediators (e.g., histamine, serotonin and prostaglandins) that are secreted from mast cells play pivotal roles in the onset and development of inflammation, the inhibitory effects of AFGS on histamine and serotonin probably contribute to the anti-inflammatory action.

In conclusion, the $70 \%$ ethanolic extract from the anomalous fruits of $G$. sinensis exhibits an inhibitory effect on immediate allergic reactions and acute inflammation, which can be mediated by reducing the release of mediators from mast cells and weakening the inflammatory effects of these mediators. Further studies are needed to elucidate the precise mechanism of action and effective constituents of $G$. sinensis.

Acknowledgement Partial support was received with gratitude from the Innovation Technology Fund (AF/281/97) of the Government of the Hong Kong Special Administrative Region.

\section{REFERENCES}

1) Jiangsu New Medical College, "Zhongyao Dacidian (Encyclopedia of Chinese Materia Medica)," Shanghai Scientific \& Technological Press, Shanghai, 1979, pp. 1144, 1145, 2198.

2) Shin T., Kim D. K., Arch. Pharm. Res., 23, $401-406$ (2000).

3) Chen N. Y., Zhao M. L., Chin. J. Pathophysiol., 12, 596-599 (1996).

4) Zhang Z., Koike K., Jia Z., Nikaido T., Guo D., Zheng J., J. Nat. Prod., 62, 740-745 (1999).

5) Zhang Z., Koike K., Jia Z., Nikaido T., Guo D., Zheng J., Chem. Pharm. Bull., 47, 388-393 (1999).

6) Zhang Z., Koike K., Jia Z., Nikaido T., Guo D., Zheng J., J. Nat. Prod., 62, 877-881 (1999).

7) Dai Y., Hang B. Q., Li P. Z., Tan L. W., Acta Pharmacol. Sinica, 10, 381-384 (1989).

8) Dai Y., Hang B. Q., Tan L. W., Chin. J. Pharmacol. Toxicol., 3, 96-99 (1989).

9) Zhou C. C., Sun X. B., Gao H. B., Liu W., Li W. T., Shi H. B., Jin C. H., Chin. J. Pharmacol. Toxicol., 5, 34-37 (1991).

10) Zhou C. C., Sun X. B., Liu W., Gao H. B., Shi H. B., Wang G. Y., Yang J. P., Chin. J. Pharmacol. Toxicol., 5, 30-33 (1991).

11) Matsuda H., Dai Y., Ido Y., Yoshikawa M., Kubo M., Biol. Pharm. Bull., 20, 1165-1170 (1997).

12) Matsuda H., Dai Y., Ido Y., Ko S., Yoshikawa M., Kubo M., Biol. Pharm. Bull., 20, 1086-1091 (1997).

13) Shin T. Y., Park J. H., Kim H. M., J. Ethnopharmacol., 66, 319-325 (1999).

14) Kubo M., Matsuda H., Tokuoka K., Ma S., Shiomoto H., Biol. Pharm. Bull., 17, 262-265 (1994).

15) Kimata M., Inagaki N., Nagai H., Planta Med., 66, 25-29 (2000).

16) Zitterl-Eglseer K., Sosa S., Jurenitsch J., Schubert-Zsilavecz M., Della Loggia R., Tubaro A., Bertoldi M., Franz C., J. Ethnopharmacol., 57, 139-144 (1997). 